JKEP

Vol 5, No 1, Mei 2020

ISSN: 2354-6042 (Print)

ISSN : 2354-6050 (Online)

\title{
Pengalaman Perawat Dalam Memberikan Layanan Melalui Sistem BPJS (Badan Penyelenggara Jaminan Sosial)
}

\author{
Lailatul Kodriyah, Ronal Surya Aditya, Listyawati Ratna Ningrum \\ STIKes Kepanjen Malang, Indonesia \\ Email :suryaronal@gmail.com
}

Artikel history

Dikirim, Dec $16^{\text {th }}, 2019$

Ditinjau, April $26^{\text {th }}, 2020$

Diterima, May $4^{\text {th }}, 2020$

\begin{abstract}
BPJS is one of the government policies in the health sector. This BPJS program established by the government is used as one of the solutions to solve problems related to health problems that arise. This study aims to find out more about the experience of nurses in providing services with the BPJS system. This research was conducted descriptively Qualitative research using a phenomenological approach was carried out on 20 to 27 November 2019. Data were obtained by in-depth interviews with nurses working in Malang Hospital and analyzed the data analysis process with Interpretative Phenomenological Analysis (IPA). The population of this study was 5 respondents. The method of selecting participants was carried out using a purposive sampling technique. Age of respondents 30 to 45 years. The results found 3 themes, namely: service incentives, satisfaction and service. Conclusion: One of the services involved in the BPJS program is Nurse. those in conducting services have the right to service incentives, because that has several obstacles that create dissatisfaction. Health workers already have maximum performance. This research is expected in the future can be the basis for making decisions for awarding and better service systems. Further research recommendations are about nurse satisfaction with services.
\end{abstract}

\begin{abstract}
ABSTRAK
BPJS (Badan Penyelenggara Jaminan Sosial) adalah salah satu kebijakan pemerintah dibidang kesehatan. Program BPJS ini yang dibentuk oleh pemerintah ini digunakan sebagai salah satu solusi pemecahan masalah terkait dengan masalah kesehatan yang muncul. Penelitian ini bertujuan untuk mengetahui lebih dalam pengalaman perawat dalam memberikan pelayanan dengan sistem BPJS. Penelitian ini dilakukan secara deskriptif Penelitian kualitatif menggunakan metode pendekatan fenomenologis dilakukan pada bulan November 20 hingga 27 November 2019. Data yang diperoleh dengan in-depth interview kepada perawat yang bekerja di Rumah Sakit Malang dan dianalisis proses analisis data dengan Interpretative Phenomenological Analysis (IPA). Populasi penelitian ini adalah 5 responden. Metode pemilihan peserta dilakukan dengan teknik purposive sampling. Usia responden $30 \mathrm{~s} / \mathrm{d} 45$ tahun. Hasil penelitian
\end{abstract}


menemukan 3 tema, yaitu : Jasa Pelayanan, kepuasan dan pelayanan. Kesimpulan : Pelayanan dalam program BPJS ini salah satunya yang terlibat didalamnya adalah Perawat. mereka dalam melakukan pelayanan memiliki hak dalam insentif jasa pelayanan, karena hal tersebut yang memilik beberapa kendala hingga muncul ketidakpuasan. Tenaga kesehatan sudah memiliki performa kinerja yang maksimal. Penelitian ini diharapkan di masa depan dapat menjadi dasar untuk mengambil keputusan untuk pemberian penghargaan dan sistem pelayanan yang leih baik. Rekomendasi penelitian selanjutnya adalah tentang kepuasan perawat terhadap jasa pelayanan.

Kata kunci : BPJS, Perawat, Pelayanan,

\section{PENDAHULUAN}

BPJS adalah salah satu kebijakan pemerintah yang fokus di kesehatan. Program BPJS ini yang dibentuk oleh pemerintah ini digunakan untuk solusi pemecahan masalah terkait dengan masalah kesehatan yang muncul. BPJS memiliki beberapa hal negatif dalam hal pelayanan. Pelayanan dalam program ini salah satunya adalah Tenaga Kesehatan. Tenaga Kesehatan adalah lini pertama kontak secara langsung dengan peserta BPJS (Intarti dkk, 2018).

Menurut World Health Organization (WHO), pengertian Sumber Daya Manusia (SDM) kesehatan adalah semua orang yang kegiatan pokoknya ditujukan untuk meninggikan kesehatan (Keliat, 2012).

Tenaga Kesehatan adalah setiap orang yang mengabdikan jiwa dan raga dalam bidang kesehatan serta memiliki pengetahuan dan/atau keterampilan melalui pendidikan di bidang kesehatan yang untuk jenis tertentu memerlukan kewenangan untuk melakukan upaya kesehatan (Aditya, 2019). Pemerintah berfokus pada peningkatan pelayanan, namun untuk mendukung hal tersebut, perlu perhatian pada tenaga kesehatan khusunya perawat. Penelitian lain berpendapat bahwa kepuasan seseorang dipengaruhi oleh penghargaan yang diberikan. Hal ini sejalan dengan fenomena perawat di lapangan. Tingginya beban kerja dan kurangnya penghargaan perawat, dapat mempengaruhi sistem pelayanan.

Sistem BPJS sudah dilaksanakan sesuai dengan kebiajakan yang ada. Pada penelitian sebelumnya hanya fokus tentang kepuasan pasien dalam penerimaan pelayanan melalui adanya system BPJS. Namun belum ada yang menggali lebih dalam ke tenaga kesehatan khususnya perawat dalam melayani pasien dengan sistem BPJS.

Pernyataan di atas mendorong peneliti untuk menggali lebih dalam pengalaman perawat melayani masyarakat yang menggunakan BPJS. Penelitian ini diharapkan di masa 
depan dapat menjadi dasar untuk mengambil keputusan untuk pemberian penghargaan dan sistem pelayanan yang leih baik.

\section{METODE}

Penelitian ini dilakukan secara kualitatif menggunakan pendekatan fenomenologis (Yusuf et al., 2017). Dengan menggunakan metode ini, peneliti ingin mengungkapkan makna suatu konsep atau fenomena pengalaman berdasarkan kesadaran yang terjadi pada beberapa individu. Penelitian ini dilakukan pada bulan November 20 hingga 27 November 2019. Metode pemilihan peserta dilakukan dengan menggunakan probabilitas dasar pengambilan sampel dengan teknik purposive sampling, yang dianggap cocok untuk kita kriteria. Sebanyak 5 peserta yang diwawancarai di Penelitian ini adalah tenaga medis yang berada di Rumah Sakit Malang dengan usia 30 tahun hingga 45 tahun (diberi kode sebagai P1, P2, P3, P4, P5). Semua peserta adalah Tenaga Medis di Rumah Sakit Malang, Semua peserta menyatakan keinginan mereka untuk memberikan informasi yang dibutuhkan oleh peneliti untuk mencapai tujuan dari penelitian ini. Pengumpulan data dalam penelitian ini dilakukan dengan wawancara mendalam menggunakan suara perekam dan teknik observasi langsung. Wawancara dilakukan secara struktural dengan menggunakan pedoman wawancara disusun oleh peneliti berdasarkan teori respon dan teori phycology. Semua data diperoleh dari mendalam wawancara kemudian dianalisis menggunakan Interpretatif Analisis Fenomenologis (IPA) (Aditya, Solikhah and Kurniawan, 2019). Penelitian ini dilakukan secara deskriptif Penelitian kualitatif menggunakan metode pendekatan fenomenologis dilakukan pada bulan November 20 hingga 27 November 2019. data diperoleh melalui wawancara mendalam kepada perawat yang bekerja di Rumah Sakit A.

\section{HASIL DAN PEMBAHASAN}

Data yang telah didapatkan ini adalah data dari responden yang homogen dengan kriteria usia 30sampai 45 tahun, tenaga kesehatan yang bekerja di Rumah Sakit Malang. Jumlah partisipan dalam penelitian ini dapat ditentukan dengan saturasi data yang digambarkan oleh tabel 1 . 
Tabel 1. Tema dan sub tema responden.

\begin{tabular}{cccccccc}
\hline No & Tema & Subtema & 1 & 2 & 3 & 4 & 5 \\
1 & Sesuai jadwal & $\sqrt{ }$ & $\sqrt{ }$ & $\sqrt{ }$ & $\sqrt{ }$ & $\sqrt{ }$ \\
& Jasa Pelayanan & Terlambat & $\sqrt{ }$ & $\sqrt{ }$ & $\sqrt{ }$ & $\sqrt{ }$ & $\sqrt{ }$ \\
& & Meningkat & $\sqrt{ }$ & $\sqrt{ }$ & $\sqrt{ }$ & $\sqrt{ }$ & $\sqrt{ }$ \\
2 & Kepuasan & Menurun & $\sqrt{ }$ & $\sqrt{ }$ & $\sqrt{ }$ & $\sqrt{ }$ & $\sqrt{ }$ \\
3 & Pelayanan & Terbaik & $\sqrt{ }$ & $\sqrt{ }$ & $\sqrt{ }$ & $\sqrt{ }$ & $\sqrt{ }$ \\
\hline
\end{tabular}

Tema 1: Jasa Pelayanan

Tenaga Kesehatan dalam memberikan pelayanan kepada pasien terdapat jasa pelayanan, dimana jasa pelayanan adalah hak dari setiap tenaga kesehatan yang telah menyelesaikan tupoksinya sesuai dengan prosedur yang telah ditetapkan dimana dalam situasi tersebut terdapat perbedaan sebelum dan sesudah adanya Asuransi Kesehatan atau BPJS dimana sebelumnya insentif jasa pelayanan berjalan dengan lancar dibutkikan pada responden "dulu mbak enak mbak lancar jaspel kami itu, gak pernah telah, ya lancar mbak" $p 1, p 2, p 3, p 4, p 5$. Setelah diberlakukannya BPJS dalam rumah sakit tersebut terdapat pemberian insentif yang kurang berjalan lancar dibuktikan pada responden "heem, sekarang ini mbak, seret, keluarnya sulit kalau gak ikut telat mbak" p1,p2,p3,p4,p5.

Hasil penelitian tema pertama adalah Jasa Pelayanan, dimana jasa pelayanan tertuang dalam Peraturan Meteri Kesehatan Republic
Indonesia No 12 Tahun 2013 tentang Pola biaya badan Layanan Umum di Lingkungan Rumah Sakit. Jasa Pelayanan ini berjalan lancar atau pun tidak lancar hal ini sejalan dengan peraturan di instansi masing-masing sesuai dengan penetapan tarif rasional (Ika Widiastuti, 2017) layanan kesehatan di Rumah Sakit. Berdasarkan penelitian sebelumnya jasa pelayanan tergantung dari jumlah pasien (Barus, 2017). Namun dalam penelitian ini di rumah sakit rujukan daerah harus menunggu dan bahkan pemerintah belum membayar klaim rumah sakit, sehingga berdampak pada pemberian insentif.

\section{Tema 2: Kepuasan}

Dalam pemberian jasa pelayanan, terdapat suatu kepuasan yang muncul pada tenaga medis, Kepuasan ini adalah dalam artian tenaga medis merasa puas dengan pemberian jasa pelayanan yang tepat waktu dan sesuai dengan yang diharapkan. Dimana terdapat perbedaan antara sebelum dan 
sesudah adanya asuransi kesehatan bpjs ini yang telah berlaku dalam 3 tahun terakir. Sebelum berlakunya BPJS di Rumah Sakit Malang terdapat kepuasan dibuktikan dengan pernyataan berikut

"ya saya dulu seneng mbak, puas dengan semuanya, pelayanan yang kami berikan ternayata insentifnya dari jaspel tadi itu tepat waktu mbak dan sesuai mbak, ya merasa puas aja intinya" p1,p2,p3,p4,p5 namun setelah diberlakukannya asuransi kesehatan tersebut muncul ketidakpuasan dibutkikan pada rata-rata pernyataan responden "owalah mbak sekarang ini ya jujur belum puas mbak, keluarnya sering telat mbak jaspel kami ini” p1,p2,p3,p4,p5.

Pembayaran Jasa layanan yang tidak tepat waktu akan terhubung dengan kepuasan pegawai (Wei, Zhang and Li, 2018), berdasarkan penelitian sebelumnya bahwa kepuasan ini akan berpengaruh pada kualitas layanan(Aditya et al., 2020). Dimana kepuasan pekerja sangat sejalan dengan performa pelayanan yang mempengaruhi mutu dari suatu instansi tersebut. Namun dalam penelitian ini, kepuasan bukan hanya tentang insentif tetapi peningkatan jenjang karir. Pada prakteknya jenjang karir ini perlu waktu sehingga perlu ada kebijakan yang mengaturnya lebih efektif dan efisien.

\section{Tema 3: Pelayanan}

Pelayanan adalah hal mutlak yang harus diberikan kepada pasien. Dimana dalam pemberian pelayanan tersebut sebelum ada BPJS atau sudah berlaku BPJS sudah maksimal dibuktikan pada permyataan responden "ya dari dulu sudah maksimal biar pasien puas dan kembali kesini lagi kalau sakit mbak, maksimal sudah yang kita kerjakan selama ini” p1,p2,p3,p4,p5.

Tenaga medis dalam pemberian layanan baik sebelum ada BPJS ataupun telah diberlakukannya BPJS dalam performa kinerja sudah maksimal. Hal ini akan sejalan dengan mutu layanan yang dapat meningkatkan income dari suatu instansi. Mutu layanan yang baik akan memberikan kepuasan pada konsumen, sehingga akan dapat kembali meningkatkan income suatu instansi tersebut (Yandrizal et al., 2018).

Menjadi daya tarik bagi masyarakat. Jika suatu Rumah Sakit melayani pasien menggunakan BPJS, Pada penelitian yang sebelumnya terkait dengan layanan BPJS bahwa ada pengaruh kualitas pelayann BPJS dengan kepuasan pasien, namun penelitian tersebut lebih focus ada kepuasa pasien (Abidin,2016). Pada penelitian ini ditemukan pelayanan berusaha untuk 
maksimal agar masyarakat meningkat kepuasannya. Pemberian pelayanan yang menguntunkan salah satu sisi, akan menyebabkan ketimpangan dan kesalahan. Hal ini yang ditemukan oleh peneliti, bahwa mereka kalau bekerja kurang semangat, terpaksa, terkadang melakukan kesalahan.

Kedepannya dengan dasar data hasil penelitian ini, pemegang kebijakan dapat mempertimbangkan pemberian insentif yang efektif dan efisien serta memberikan inovasi dalam meningkatkan kinerja perawat.

\section{KESIMPULAN}

Pelayanan dalam program BPJS melibatkan tenaga kesehatan khususnya perawat dalam melakukan pelayanan. Pemberian jasa pelayanan adalah hak dalam insentif jasa pelayanan, keterlambatan akan menimbulkan ketidakpuasan bagi perawat, sehingga berdampak pada mutu pelayanan. Kepuasan perawat, ditentukan oleh penghargaan berupa insentif. Penghargaan bisa berupa jenjang karis. Tetapi jenjang karir yang belum menentu, sehingga mereka fokus pada insentif.

Tenaga kesehatan sudah memiliki performa kinerja yang maksimal. Perawat dalam memberikan layanan melalui sistem BPJS tersebut memiliki 3 dampak peranan penting selama melakukan asuhan keperawatan kepada pasien yaitu pada bidang Jasa pelayanan selama melakukan perawatan kepada pasien, kepuasan pada system BPJS tersebut dan pelayanan kepada pasien.

\section{DAFTAR PUSTAKA}

Aditya, R. S. (2019) Perbandingan Metode Health Coaching dan Ceramah Tentang Basic Life Support (BLS) Untuk Remaja Masjid, Jurnal Keperawatan BSI. Available at: http://ejurnal.univbsi.id/index.php/kep erawatan/article/view/105 (Accessed: 1 November 2019).

Aditya, R. S. et al. (2020) Pengantar Antropologi Kesehatan. 1st edn. Edited by M. F. Arifin. Malang: Literasi Nusantara.

Aditya, R. S., Solikhah, F. K. and Kurniawan, S. B. (2019) 'Teenager response to the conditions of basic level emergency: A phenomenology study', Indian Journal of Public Health Research and Development, 10(9). doi: 10.5958/09765506.2019.02421.5.

Barus, G. (2017) 'Assessing Outcomes and Effectiveness of Character Education Model Based on Classroom Guidance Services in Junior High Schools', COUNS-EDU: The International Journal of Counseling and Education, 2(3), pp. 131-143. 
Ika Widiastuti (2017) 'SOCIAL SECURITY GUARANTEE (BPJS) SERVICES IN WEST JAVA', pp. 91-101. Available at:

http://www.ghbook.ir/index.php?name ى هل

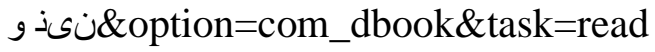
online\&book_id $=13650 \&$ page $=73 \& \mathrm{ch}$ khashk=ED9C9491B4\&Itemid=218\&1 ang $=$ fa\&tmpl=component.

Intarti dkk, W. D. (2018) 'Factors that Influence Utilization of Elderly Posyandu', Journal of Health Studies, 2(1), pp. 110-122. doi: 10.31101/jhes.439.

Keliat, A. et al (2012) Keperawatan Jiwa Komunitas CMHN (Basic Course). EGC.
Wei, Y., Zhang, H. and Li, X. (2018) 'Youth and teenager health service in community organizing: prevention health care in China', International Journal of Adolescence and Youth. Routledge, 00(00), pp. 1-9. doi: 10.1080/02673843.2018.1524331.

Yandrizal et al. (2018) 'Stakeholder collaboration model to empower integrated health education centers for non-communicable diseases: A study in Bengkulu', Indian Journal of Public Health Research and Development, 9(1), pp. 133-138. doi: 10.5958/09765506.2018.00025.6.

Yusuf, A. et al. (2017) Riset Kualitatif Dalam Keperawatan. 1st edn. Surabaya: Mitra Wacana Media. 